\title{
EFFECT OF WORK ENVIRONMENT, LEADERSHIP, COMPENSATION, AND WORK TRAINING ON EMPLOYEE ENGAGEMENTS IN STAR HOTELS IN BATAM
}

\author{
Antony S \\ Universitas Internasional Batam \\ Corresponding author: antony.sentoso@yahoo.com
}

\begin{abstract}
The purpose of this study is to analyze the factors that affect employee retention. Factors that affect employee retention are SHRM Practices, including recruitment \& Selection, Training \& Career Development, Performance Appraisal, and Compensation \& Benefits. There are also other factors, namely Demographic \& Professional Characteristics. This research uses the purposive sampling method, and the data is processed using PLS. The number of respondents in this study was 259 out of 270 questionnaires distributed. This study's Respondents were employees of 4-star hotels in Batam, which had satisfactory scores on the travel site, Traveloka, above 8.6. Based on the research results and the data that have been processed, the SHRM practices variable has a significant effect on the employee retention variable. Where terms of recruitment, training, compensation, and benefits have a positive influence on employee retention
\end{abstract}

Keywords: SHRM Practices, Recruitment \& Selection, Training \& Career Development, Performance Appraisal, Compensation \& Benefit, Demographic \& Professional Characteristics.

\section{Introduction}

In the current era of globalization, there have been many companies that have established various businesses. In this case, the company has an essential role in producing quality human resources to be carried out through several training and others. In the world of work, recruitment is a fundamental thing to do for selecting workers - both in terms of knowledge and abilities.

Like the conditions currently in crisis due to the current coronavirus, many companies have terminated contracts (layoffs) or dismissed their employees without any payment. Reporting from coverage 6 (https://www.liputan6.com/bisnis/read/4219869 / list-1139-hotel-closed-due to-corona-several-layoffs), 1,139 hotels were temporarily closed, as many as 1,174 hotels decided its working relationship with employees. This, of course, impacts employee turnover due to many employees leaving the company, where the company loses many employees who have good performance potential due to not being able to pay the salaries that must be paid.

A company can also be said to lose its employees because the loss includes capital, whether it be money, expertise, knowledge, or other essential matters. The company needs to be able to maintain and prevent the loss of its employees.

Seeing that Batam is a city where many industries and companies are established, it would be nice to know how vital employee retention is. In other words, if we as entrepreneurs can manage employee management to know how to retain employees who have good potential and impact the company's progress, there is no leaving of employees in the company which will cause losses and inefficiency in work the company.

As it is known, the bigger the employee feels that his workplace puts more priority on his employees' welfare. The employee must also have a minimal initiative to leave the company. Conversely, if the company does not care about its employees' welfare, this can trigger a high level of employees who will leave the company.

Recruitment \& Selection has a positive influence on satisfaction / motivators / intrinsic factors. In this case, there is a relationship to motivation because, in the selection, it is essential so that workers can be more skilled. According to researcher Mc Clelland (2017), motivation serves as a driving force that enables workers and organizations to provide expertise, energy, and time to carry out their obligations to achieve the specified goals and objectives.

Training \& Career Development has a positive influence on dissatisfiers/hygiene / extrinsic factors. The purpose of training is to improve work quality, increase work productivity, and improve employee personal development, and this is, of course, related to extrinsic factors where the worker wants to take action such as working harder and continuing to develop his / her abilities (Suwanto \& Priansa, 2011).

Performance Appraisal has a positive influence on General Satisfaction. With a job appraisal system that is done well, it can increase job satisfaction. For instance, such as fairness, which includes aspects of transparency, accuracy, and punctuality, can improve and positively affect job satisfaction.

Compensation \& Benefit has a positive influence on General Satisfaction. According to Ardana (2012), compensation is any form received by employees as remuneration for their contribution to a company or 
organization. This can affect job satisfaction because compensation is remuneration for work to keep workers working at the company and motivate workers to do their job as well as possible.

Demographic \& Professional Characteristics have a positive influence on SHRM Practices and Employee Retention. According to Nurdin and Adiotomo (2011), demographics consist of age, gender, and ethnicity, influencing individual-level independent behavior. This statement affects employee retention and human resource practice because companies need workers who are ready to work according to age, gender, and professional character to meet predetermined targets.

Employee retention is a company effort or action to retain its employees, not to leave the company. This is so that employees who have good performance can continue working in the company. Thus the company does not lose any of its valuable assets, and its operations can run well. Apart from this, the company wants employees to be loyal and comfortable working in the company, considering that the company also incurs costs for recruiting and providing training (Susilo, 2013).

In this case, there is a relationship to motivation because, in the selection, it is essential so that workers can be more skilled. According to researcher Mc Clelland (2017), motivation serves as a driving force that enables workers and organizations to provide expertise, energy, and time to carry out their obligations to achieve the specified goals and objectives.

The purpose of training is to improve work quality, increase work productivity, and improve employee personal development, and this is, of course, related to extrinsic factors where the worker wants to take action such as working harder and continuing to develop his / her abilities (Suwanto \& Priansa, 2011).

With a job appraisal system that is done well, it can increase job satisfaction. For example, fairness, which includes aspects of transparency, accuracy, and punctuality that can improve and have a positive effect on job satisfaction.

According to Ardana (2012), compensation is any form received by employees as remuneration for their contribution to a company or organization. This can affect job satisfaction because compensation is remuneration for work to keep workers working at the company and motivate workers to do their job as well as possible.

According to Nurdin and Adiotomo (2011), demographics consist of age, gender, and ethnicity, influencing individual-level independent behavior. This statement affects employee retention and human resource practice because companies need workers who are ready to work according to age, gender, and professional character to meet predetermined targets.

The hypothesis is an essential scientific research tool that aims to help researchers carry out a process of analysis that combines two or more variables. The study was conducted to formulate two hypotheses to be tested to influence the independent variable on the dependent variable. By taking the research model of Waiganjo et al., (2012), the researcher proposes the following hypothesis.

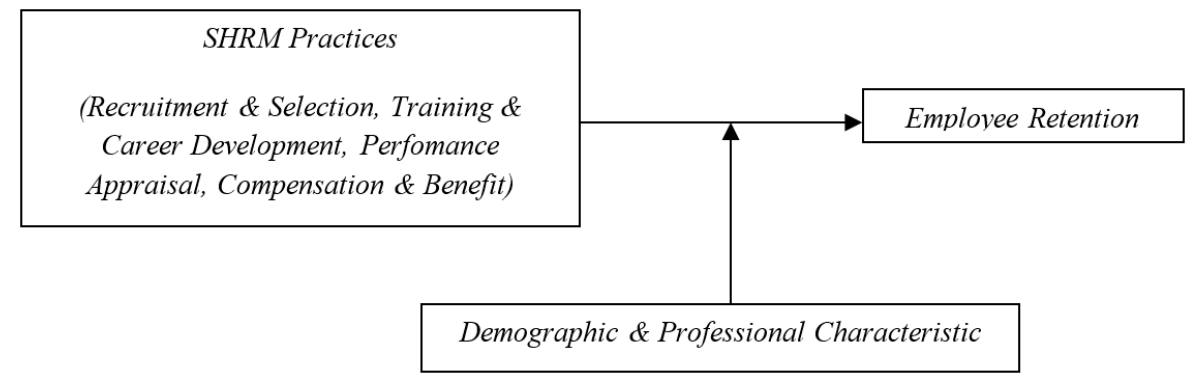

Figure 1. Conceptual Framework

H1: There is a significant positive effect between SHRM Practices on Employee Retention.

H2: There is a significant positive effect between SHRM Practices and employee retention through demographic \& professional characteristics as moderation.

\section{Research Method}

In general, the research method is a stage where the method aims to find answers to a problem and achieve a process that produces a good ending. The number of research methods that can be used can be adjusted according to the data collected. In this research method, researchers use associative quantitative data methods to determine the cause and effect among the existing variables.

Data collection techniques in observation, filling out questionnaires, and supported by internet searches and documenting. This research aims to provide input that companies can use in terms of employee retention, benefits, and adding insight to society and future research.

The population for this study was workers in hotels, especially four-star hotels in Batam. A hotel is a place of lodging for tourists and residents where the hotel will provide services for room rental, various meals or dishes and drinks, and other facilities that support the accommodation prices that have been given (Decree 
of the Minister of Tourism, Post and Telecommunications No. KM 37 / PW . 340 / MPPT-86., 2011). In the hotel classification (based on stars), the hotel has a 1 star to 5 -star qualification.

In conducting the research method process, researchers distributed questionnaires to 5 4-star hotels in Batam, where the hotel received excellent scores, namely above 8.5 on the travel site, Traveloka. The questionnaire was distributed quickly and was right on target so that the target number of respondents was met and the collected data could be collected directly.

Each star hotel will have its facilities and advantages and disadvantages. The higher the star of a hotel, the better and complete the facilities and services provided. This study's sample consisted of five four-star hotels in Batam that scored 8.6 and above on the travel site, namely Traveloka. The hotels are Best Western Premier Panbil, Aston, I Hotel Baloi, Nagoya Hill Hotel, and ibis Styles Nagoya.

Determination techniques in sampling, researchers, use the table Krejcie and Morgan (1970). Krejcie and Morgan's (1970) table is effortless and easy to use because it only has two columns for the population size (N) and sample size (n). Whereby looking at the table, researchers can immediately estimate the number of samples of respondents who must be collected. Based on the population size, the total number of employees at the five 4 star hotels is 514 , so the sample required is at least 226 . To avoid the lack of data collected, the authors distributed 270 questionnaires.

\section{Result and Discussion}

The variance value in data that has been processed according to Harman's Single Factor in the SPSS application program obtained is $45.735 \%$. Where if this number does not exceed $50 \%$, the data is declared there are no common method biases.

Outer loading test results are declared valid if the sample mean value is above 0.5 and vice versa if the value obtained is below 0.5 , then it is not valid. As the results obtained, all questions are declared valid because the value obtained is above 0.5 .

The validity test results aim to measure the coefficient level of whether the variable is suitable for use or not. Average Variance Extracted (AVE) value is declared valid if the value is more significant than 0.5 , and if the value is below that, the variable is invalid. The Demographic \& professional characteristics variable has an AVE value of 0.729. Employee Retention has an AVE value of 0.616, and SHRM practices have an AVE value of 0.661 , which can be concluded that each variable's value has a value above 0.5 , which means valid.

Reliability test is carried out on previously considered valid; in this analysis, the reliability test is useful to determine the coefficient's level. Variables that have a Cronbach's Alpha value above 0.5 are declared valid (Ghozali, 2008). Demographic \& Professional Characteristics shows a value of 0.737, Employee Retention with a value of 0.947 , and SHRM Practices shows a value of 0.953. All of these variables have a Cronbach's Alpha value above 0.5 means reliability.

The inner model describes the relationship between latent variables. A variable can be significant if it has a P-value $<0.05$ or a T-statistics of more than 1.96 (Hair et al. 2011). The influence test shows that the SHRM practices variable has a significant effect on employee retention with a T-statistic value of 20.513 , which means that the value is more than 1.96 and a P-value of 0,000 , which means that hypothesis 1 is acceptable. The test results of this study are consistent with research conducted by Fahim et al. (2018), Tangthong et al. (2014), Zahoor et al. (2015), Wijesiri et al. (2019). The influence test shows that the Demographic \& Professional Characteristics variable has no significant effect on employee retention with a T-statistic value of 1.306, which means that the value is less than 1.96 and a P-value of 0.192, which means that hypothesis 2 cannot be accepted. The test results of this study are not consistent with research conducted by Das et al. (2013), Azeez et al. (2017), Sarmad et al. (2016), Anis et al. (2011).

According to Ghozali (2012: 97), the coefficient of determination (R2) test is used to measure how far the model can explain variations in the dependent variable. The results in table 4.13 state that employee retention has an R Square value of 0.347 , which means that SHRM practices affect employee retention by $34.7 \%$.

In order to know the overall value of the research model, the Quality Index was conducted. This test is done by calculating the GoF value with the formula $\mathrm{GoF}=\sqrt{ }((\mathrm{Comm}) \overline{\mathrm{x}}(\mathrm{R} \wedge 2) \overline{)}$. The Comm value is calculated from the average AVE, while the $\mathrm{R} 2$ value is obtained from the average $\mathrm{R}$ squared. The calculation results are as follows:

$\mathrm{Comm}=(0.729+0.616+0.661) / 3=0.668$

$R^{\wedge} 2=0.347$

\section{Conclusion}

This research was conducted to determine each related variable's effect, such as the independent variable, the moderating variable, and the dependent variable. The processed research data is obtained by distributing questionnaires to 54 4-star hotels with excellent scores, namely above 8.6 on the travel site, Traveloka. The data collected were then processed so that the researcher knew the results obtained. The results obtained were whether these variables had a significant or insignificant effect. Following are the results based on the research that has been done:

1. The results of the $\mathrm{H} 1$ analysis are accepted; SHRM practices are significant on employee retention. 
2. The $\mathrm{H} 2$ analysis results are not accepted; the moderating variable has no significant effect on SHRM practices and employee retention.

The researcher's recommendation for future researchers can increase the sample under study to clarify and strengthen the research results. The next researcher can add to the number of other variables such as career development opportunities, organizational environment, supervisory support, etc. So it can be seen whether these variables also have a significant effect. Then use other approaches such as using google forms, telephone interviews, etc.

The researcher's recommendation for companies is to know that employee retention must be done by companies so that employees who have good potential and performance can still feel at home working at the company and do not cause any intention to leave. Companies must pay attention to the welfare of their employees so that the atmosphere at work is better.

\section{References}

Ajmal, M. M., Shamim, M., \& Saleh, M. (2016). Journal of Behavioural Sciences. Journal of Behavioural Sciences, 26(2), 1-15.

Atif, A., Kashif your Rehman, Ijaz Ur Rehman, Muhammad, A. K., \& Asad, A. H. (2011). Impact of organizational commitment on job satisfaction and employee retention in the pharmaceutical industry. African Journal of Business Management, 5(17), 7316-7324. https://doi.org/10.5897/ajbm10.1296

Azeez, S. (2017). Human Resource Management Practices and Employee Retention: A Review of Literature. Journal of Economics, Management, and Trade, 18(2), 1-10. https://doi.org/10.9734/jemt/2017/32997

Bibi, P., Ahmad, A., \& Majid, A. H. A. (2018). The impact of training and development and supervisors support on employees retention in academic institutions in Pakistan: The moderating role of the work environment. Gadjah Mada International Journal of Business, 20(1), 113-131. https://doi.org/10.22146/gamaijb.24020

Das, B. L. (2013). Employee Retention: A Review of Literature. IOSR Journal of Business and Management, 14(2), 08-16. https://doi.org/10.9790/487x-1420816

Fletcher, L., Alfes, K., \& Robinson, D. (2018). The relationship between perceived training and development and employee retention: the mediating role of work attitudes. International Journal of Human Resource Management, 29(18), 2701-2728. https://doi.org/10.1080/09585192.2016.1262888

Gul, Asiya; Akbar, Sajjad; Zeb, J. (2012). Role of capacity development, employee empowerment, and promotion on employee retention in Pakistan's banking sector. International Journal of Academic Research in Business and Social Sciences, 2(9), 284-300.

Haider, M., Rasli, A., Akhtar, C. S., Yusoff, R. B. M., Malik, O. M., Aamir, A., Arif, A., Naveed, S., \& Tariq, F. (2015). The impact of human resource practices on employee retention in the telecom sector. International Journal of Economics and Financial Issues, 5(2), 63-69.

Imna, M., \& Hassan, Z. (2015). Influence of Human Resource Management Practices on Employee Retention in Maldives Retail Industry. International Journal of Accounting and Business Management, 4(2), 50-80. https://doi.org/10.24924/ijabm/2015.04/v3.iss $1 / 50.80$

Janjua, B. H., \& Gulzar, A. (2014). The Impact of Human Resource Practices on Employee Commitment and Employee Retention in Telecom Sector of Pakistan: Exploring the Mediating Role of Employee Loyalty. IOSR Journal of Business and Management, 16(1), 76-81. https://doi.org/10.9790/487x-16167681

Jawaad, M., Amir, A., Bashir, A., \& Hasan, T. (2019). Human resource practices and organizational commitment: The mediating role of job satisfaction in the emerging economy. Cogent Business and Management, 6(1), 1-22. https://doi.org/10.1080/23311975.2019.1608668

Mahfoozi, A., Salajegheh, S., Ghorbani, M., \& Sheikhi, A. (2018). Developing a talent management model using government evidence from a large-sized city, Iran. Cogent Business and Management, 5(1), 1-15. https://doi.org/10.1080/23311975.2018.1449290

Sendawula, K., Nakyejwe Kimuli, S., Bananuka, J., \& Najjemba Muganga, G. (2018). Training, employee engagement and employee performance: Evidence from Uganda's health sector. Cogent Business and Management, 5(1), 1-12. https://doi.org/10.1080/23311975.2018.1470891

Tangthong, S., Trimetsoontorn, J., \& Rojniruntikul, N. (2014). HRM Practices and Employee Retention in Thailand-A Literature Review. International Journal of Trade, Economics, and Finance, 5(2), 162-166. https://doi.org/10.7763/ijtef.2014.v5.362

Wijesiri, N. R. A. S. S., Paranagama, G. S., Sirirwardhana, M. M. A. S., Thilakarathna, D. L. N. C., Weerarathna, R. ., \& Pathirana, U. P. G. . (2018). The Impact of HR Practices on Employee Retention; A Case of BPO Sector, Sri Lanka. International Journal of Human Resource Studies, 9(1), 1. https://doi.org/10.5296/ijhrs.v9i1.14050 